\title{
How to Overcome Transformation Barriers in IT Departments of State-Owned Enterprises
}

\author{
Christoph Ertl, M.Sc. (Corresponding author) \\ Chair for Information Systems, Technical University of Munich \\ Boltzmannstr. 3, 85748 Garching, Germany \\ E-mail: mail@christoph-ertl.de
}

Dr. Alexander Herzfeldt

Chair for Information Systems, Technical University of Munich

Boltzmannstr. 3, 85748 Garching, Germany

E-mail: aherzfeldt@gmx.de

Prof. Dr. Helmut Krcmar

Chair for Information Systems, Technical University of Munich

Boltzmannstr. 3, 85748 Garching, Germany

E-mail: krcmar@in.tum.de

Received: Jan. 7, 2018 Accepted: Jan. 19, 2018 Published: Feb. 22, 2018

doi:10.5296/jpag.v8i1.12696 URL: https://doi.org/10.5296/jpag.v8i1.12696

\begin{abstract}
This paper develops a framework for analyzing organizational change in information technology (IT) departments of state-owned enterprises (SOEs) and applies that framework to a case study of a German airport that is majority-owned by the German federal government. Specifically, we derive a framework from literature to systematically identify transformation barriers for introducing new enterprise resource planning (ERP) systems and business processes in IT departments of SOEs. This framework is based on the punctuated equilibrium model and considers dynamic process incorporation, explicit stakeholder integration, a detailed representation of the change process, and characteristics of public employees as main factors. We then apply the framework in a case study research approach and show how the
\end{abstract}


framework allows identification of transformation barriers hidden to management but involved in the organizational change process (e.g., required change of organizational structures, required change of service-level-agreements). The framework can be a valuable tool for both researchers and practitioners to actively shape the effects of organizational transformation in SOEs and to identify factors that influence the change process.

Keywords: public sector, stated-owned enterprise, enterprise resource planning, organizational transformation, punctuated equilibrium model, case study research

\section{Introduction}

Organizational transformations caused by reorganizing business structures and systems are a frequent event (Ackoff, 2006; Al-Haddad \& Kotnour, 2015; Burnes, 2004; Moran \& Brightman, 2001). This applies to private enterprises as well as to state-owned enterprises (SOEs), which are directly or indirectly controlled by governmental authorities and can be found in many countries, e.g., Germany, Mexico, and China. Success rates of organizational transformation and system adoption projects in SOEs, however, have been less than $30 \%$ for several years (Balogun \& Hope Hailey, 2004; Beer \& Nohria, 2000; Jacobs, van Witteloostuijn \& Christe-Zeyse, 2013; Jansson, 2013).

Especially for SOEs, which must deal with the presence and interactions of both political and private administrative managers and need to pursue different types of strategies at the same time, e.g., providing public service and obtaining financial independence, organizational transformation projects present additional organizational layers of complexity (Vander Elst \& De Rynck, 2014). When referring to literature, one finds that transformation in public organizations does not focus predominantly on organizational but rather on strategic aspects (cf. Kromidha 2012; Vander Elst \& De Rynck, 2014), technology-related issues (cf. Cordella \& Bonina, 2012; Cordella \& Tempini, 2015; Gong \& Janssen, 2012; Haahr, 2014; Meier, Ben \& Schuppan, 2013; Mergel, 2013; Orlikowski, 1992) as well as the employer's perspective and their individual change process (Meier et al., 2013).

However, little research (cf. Puron-Cid, Gil-Garcia \& Luna-Reyes, 2012) has been addressed on organizational transformations in the information technology (IT) department of SOEs. To explore this field of research in a more systematic way, we selected the IT department within SOEs as the object of our research. The IT department is responsible for operating and supporting all necessary IT services for a SOE. Compared to other departments of SOEs, IT departments more likely face organizational transformations caused by increasing initiatives of public private partnerships in the IT sector (Sharma 2012; Da Cruz and Marques 2012), realization of IT outsourcing activities (Joha and Janssen 2010; Cordella and Willcocks 2012) or the upcoming trend of IT insourcing (Damanpour et al. 2013; Warner and Hefetz 2012). With these issues in mind, our work addresses the following research question (RQ):

RQ: How can transformation barriers in IT departments of state-owned enterprises be identified and overcome?

We will answer this research question by deriving a framework for SOEs that enables the analysis of complex interactions between organizational transformations when introducing 
new enterprise resource planning (ERP) systems and apply this framework in a case study with a German airport. Because many initiatives introducing new ERP systems and processes fail because they do not consider the broader organizational environment (Dillard, Rigsby \& Goodman 2004), an integrated approach may be necessary to systematically identify transformation barriers (Al-Haddad \& Kotnour, 2015). Thus, we build this framework on the punctuated equilibrium model and on major contributions we identified in literature.

This contribution is structured as follows: In the background section we discuss organizational attributes influencing organizational transformation at SOEs and present an overview of existing frameworks on organizational change. In the third section, we then derive a framework for analyzing the effects of organizational transformations in ERP introduction projects in the IT department of SOEs. Next, we present a case study in which our framework at a German airport is applied. We then present and discuss our findings followed by a short summarization of our research.

\section{Background}

\subsection{Characteristics of Organizational Transformation in IT Departments of State-Owned Enterprises}

Many contributions in literature can be found showing that organizational transformation projects vary significantly in private and public companies (Boyne, 2002; Nutt \& Backoff, 1993). In order to obtain a systematic overview on characteristics of transformation projects in SOEs, Ertl et al. (2014) performed a comprehensive literature review. The composition clearly reveals that organizational change projects in SOEs comprise characteristics of private organizations (e.g., the focus on output performance and a homogeneous group of customers) and other characteristics for public administrations (e.g., political influence and lower managerial autonomy). There are four attributes of the organization to be considered with regard to introducing ERP projects in SOEs (cf. Ertl et al., 2014): time horizon of managers' decisions, complexity of the decision process, organizational goals, and managerial values of the employees in the management accounting department.

The first attribute refers to the time horizon of managers' decisions. Based on OECD data, Tarschys (2002) verified that managers in the public sector face the challenge of making short-term decisions and long-term investments. This results from the influence of the supervisory board or political conditions on SOEs (Nutt and Backoff, 1993; Boubakria et al., 2008). Because major decisions of the supervisory board, which is mainly staffed with politicians, can change after an election, the management accounting of SOEs needs to have various business plans at their disposal (Tarschys, 2002).

This influence of the external environment on the organization of SOEs is also reflected in the second attribute, complexity. As the external environment of a public organization is littered with political considerations and thus drives complexity (Nutt, 2006). In contrast to economic issues, which are crucial for private organizations, the views of opinion leaders, legislators and interest groups are of great importance (Levine et al., 1975). As a result, SOEs develop numerous business plans and intricate ways of interaction with key stakeholders in 
their environment to handle the public influence on their organization (Nutt, 2006).

A third attribute to be considered when introducing projects in SOEs are the organizational goals. Ertl et al. (2014) suggest that procedures and policies based on guidelines and regulations of the public sector should be taken into consideration. Consequently, rules and routines are an integral part to align internal management accounting methods with legal requirements (De Lancer Julnes \& Holzer, 2001). Therefore, the initial third attribute, organizational goals, is replaced with the attribute bureaucracy, which describes the need for formalistic procedures of the decision process in the public sector.

The fourth organizational attribute encompasses the managerial values of managers and employees of SOEs departments. Based on empirical studies, Boyne (2002) indicated that managers and employees are less materialistic and show a weaker organizational commitment in comparison to employees of private enterprises, especially start-ups.

Figure 1 summarizes the main factors of a new ERP system and business process transformation for public administrations.

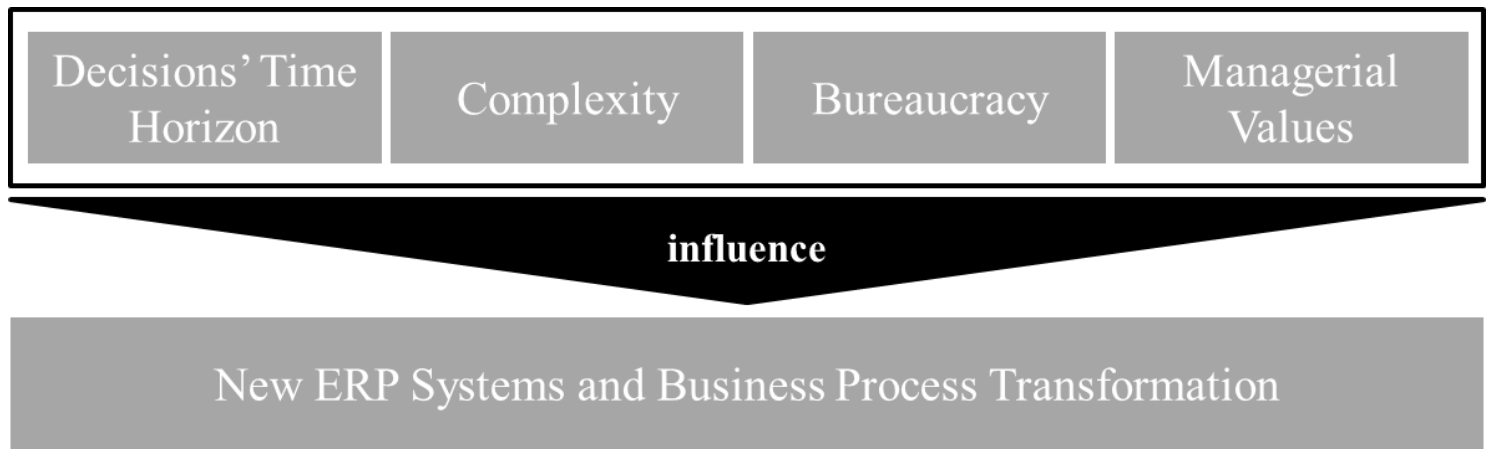

Figure 1. Overview of four key factors influencing the transformation of new ERP systems and business processes (modeled after Ertl et al., 2014)

These four factors need to be incorporated in frameworks to analyze the introduction and transformation of new ERP systems and business processes in IT departments of SOEs.

\subsection{Existing Theories and Frameworks for Organizational Change}

Organizational transformations encompass individual changes as well as modifications in structures and processes on a corporate level (Kets de Vries \& Balazs 1998). A literature review was conducted to identify existing frameworks that analyze the impact of organizational transformations on management accounting systems. The literature review was conducted based on the recommendations of Webster and Watson (2002).

First, we considered where the literature review fits into Cooper's (1988) Taxonomy of Literature Reviews. The aim of the literature review is to analyze current frameworks that conceptualize the impact of organizational transformations on the management accounting system, to criticize and integrate existing frameworks organized in a conceptual way using a neutral view for a general scholar audience and encompassing representative literature (cf. Appendix Table A.1). 
Since the focus of this research is the analysis of organizational change when introducing new ERP systems and business processes, the selection of publications is limited to journals in this field. The selection includes major management accounting and public management journals (cf. Appendix Table A.2).

Using online databases we searched the selected journals for the words 'organizational' and 'change' appearing in the search areas abstract, title and keywords. All issues of the selected journals available in the databases were included. Overall, the literature review yielded 514 articles (see Appendix Table A.2); non-relevant articles were excluded. For this purpose, we screened the titles and abstracts of all 514 articles to determine if they complied with the following criteria: 1) the article addressed changes in the management accounting department itself and 2) articles dealing with changes in specific management accounting methods were excluded. Screening for these two criteria yielded 69 useable articles. In a further screening step, all articles containing case study research were excluded because, as described above, the focus of the research is the identification and evaluation of frameworks in this field. In total, 19 articles were reviewed in detail.

The findings of the literature review are depicted in Table 1. The column 'Basic Theory' refers to the theory applied by the authors to develop their framework. In the next column, a reference is noted if the provided framework is based on the ideas of other authors. The column 'Focus' briefly describes the main idea and concept of the framework. The next columns provide the unit and the mode of change according to the concept of Van de Ven and Poole (1995). The change theory resulting from mode and unit of change is shown in the last column. 
Table 1. Frameworks analyzing the effects of organizational transformations on the management accounting system

\begin{tabular}{|c|c|c|c|c|c|c|}
\hline Article & Basic Theory & Framework & Focus & Unit of Change & Mode of Change & $\begin{array}{l}\text { Change } \\
\text { Theory }\end{array}$ \\
\hline $\begin{array}{l}\text { Abernethy \& } \\
\text { Brownell (1999) }\end{array}$ & - & Simons (1990) & \begin{tabular}{|l|} 
Develop a theoretical \\
framework to examine the \\
relationship between \\
strategic change, style of \\
budget use and performance
\end{tabular} & $\begin{array}{l}\text { Single (interactive use of budgets } \\
\text { enables the organization } \\
\text { to cope better with the change } \\
\text { process) }\end{array}$ & $\begin{array}{l}\text { Constructive (relationship } \\
\text { between } \\
\text { strategic change and } \\
\text { performance be enhanced } \\
\text { when budgets are used } \\
\text { interactively; the model } \\
\text { developed here treats budget } \\
\text { use as a variable) } \\
\end{array}$ & Teleology \\
\hline $\begin{array}{l}\text { Ahrens \& } \\
\text { Chapman (2007) }\end{array}$ & - & Schatzki (2002) & $\begin{array}{l}\text { The role of management } \\
\text { accounting in the } \\
\text { constitution of } \\
\text { organizations; } \\
\text { Interrelationships between } \\
\text { technical and interpretive } \\
\text { accounting processes }\end{array}$ & $\begin{array}{l}\text { Single (the diverse purposes of } \\
\text { organisations have on the } \\
\text { activities of their members) }\end{array}$ & $\begin{array}{l}\text { Constructive (developing } \\
\text { its potential as a structure of } \\
\text { intentionality) }\end{array}$ & Teleology \\
\hline $\begin{array}{l}\text { Applebaumet al. } \\
\text { (1998) }\end{array}$ & & $\begin{array}{l}\text { Burke \& Litwin } \\
\text { (1992); } \\
\text { Robbins (1993) }\end{array}$ & $\begin{array}{l}\text { Strategic organizational } \\
\text { change model: Determinants } \\
\text { of change, change agents, } \\
\text { change process, } \\
\text { organizational elements }\end{array}$ & Single (organizational chage) & $\begin{array}{l}\text { Prescribed (model of } \\
\text { planned organizational change) }\end{array}$ & Life-Cycle \\
\hline \begin{tabular}{|l|} 
Baines \& \\
Langfield-Smith \\
$(2003)$
\end{tabular} & - & $\begin{array}{l}\text { Own structural } \\
\text { model }\end{array}$ & $\begin{array}{l}\text { Changing competitive } \\
\text { environment; } \\
\text { Range of organizational } \\
\text { variables as antecedents to } \\
\text { accounting change }\end{array}$ & $\begin{array}{l}\text { Multiple (examine the } \\
\text { relationships between the changing } \\
\text { competitive environment) }\end{array}$ & $\begin{array}{l}\text { Constructive (range of } \\
\text { organizational variables as } \\
\text { antecedents to } \\
\text { management accounting change) }\end{array}$ & Dialectic \\
\hline $\begin{array}{l}\text { Burns \& Scapens } \\
2000\end{array}$ & $\begin{array}{l}\text { Old institutional } \\
\text { theory }\end{array}$ & $\begin{array}{l}\text { Barley \& Tolbert } \\
\text { (1997) }\end{array}$ & $\begin{array}{l}\text { Describe and explain } \\
\text { analytical concepts by a } \\
\text { modified framework; Focus } \\
\text { on fundamental } \\
\text { characteristics of change } \\
\text { processes }\end{array}$ & $\begin{array}{l}\text { Single (the "institution" represents } \\
\text { one entity) }\end{array}$ & $\begin{array}{l}\text { Prescribed (change or implement } \\
\text { new formal management } \\
\text { accounting systems as "rules") }\end{array}$ & Life-Cycle \\
\hline $\begin{array}{l}\text { Cunningham \& } \\
\text { Kempling } 2009\end{array}$ & - & $\begin{array}{l}\text { Nine principles } \\
\text { for changing } \\
\text { public sector } \\
\text { organizations }\end{array}$ & $\begin{array}{l}\text { Inputs initiating change; } \\
\text { Process assisting the } \\
\text { implementation; Outcomes } \\
\text { illustrating success }\end{array}$ & Single (a public organization) & $\begin{array}{l}\text { Prescribed (importance of } \\
\text { establishing a need for } \\
\text { change and to create a } \\
\text { consensus around this need) }\end{array}$ & Life-Cycle \\
\hline $\begin{array}{l}\text { Chenhall \& Euske } \\
2007\end{array}$ & - & Huy (2001) & $\begin{array}{l}\text { Rational, systematic } \\
\text { practices and the behavioral } \\
\text { processes; } \\
\text { Idealized intervention types: } \\
\text { commanding, engineering, } \\
\text { teaching and socializing }\end{array}$ & $\begin{array}{l}\text { Single (integrating an } \\
\text { organization's reconstituted values } \\
\text { and beliefs with particular } \\
\text { rationalities, the external } \\
\text { environmental, and social and } \\
\text { political forces that affect } \\
\text { organizational action) }\end{array}$ & $\begin{array}{l}\text { Prescribed (planned } \\
\text { organizational change }\end{array}$ & Life-Cycle \\
\hline $\begin{array}{l}\text { Dambrin et al. } \\
2007\end{array}$ & $\begin{array}{l}\text { New institutional } \\
\text { sociology }\end{array}$ & \begin{tabular}{|l} 
Hasselbladh \& \\
Kallinikos (2000)
\end{tabular} & $\begin{array}{l}\text { Implementation of change } \\
\text { processes; } \\
\text { Translation of ideas into } \\
\text { discourses and control } \\
\text { techniques }\end{array}$ & $\begin{array}{l}\text { Single (the management control } \\
\text { system of an organization) }\end{array}$ & $\begin{array}{l}\text { Prescribed (a change in the } \\
\text { institutional logic of an } \\
\text { organisational field) }\end{array}$ & Life-Cycle \\
\hline Dillard et al. 2004 & $\begin{array}{l}\text { Institutional theory; } \\
\text { Structuration theory }\end{array}$ & & $\begin{array}{l}\text { The role of accounting in the } \\
\text { change process }\end{array}$ & $\begin{array}{l}\text { Single (practice of accounting in } \\
\text { organizations) }\end{array}$ & $\begin{array}{l}\text { Prescribed (processes } \\
\text { as sociated with creating, } \\
\text { adopting and discarding } \\
\text { institutional practices) }\end{array}$ & Life-Cycle \\
\hline $\begin{array}{l}\text { Englund et al. } \\
2011\end{array}$ & Structuration theory & - & \begin{tabular}{|l|} 
Ontological basis for \\
theorizing how, when and \\
why socially embedded \\
agents \\
may produce both continuity \\
and change in accounting \\
practices
\end{tabular} & $\begin{array}{l}\text { Single (how and why accounting is } \\
\text { mobilized in and transformed } \\
\text { through "everyday" organizational } \\
\text { life) }\end{array}$ & $\begin{array}{l}\text { Constructive (structuration } \\
\text { theory cannot predict human } \\
\text { action since actors are } \\
\text { knowledgeable and reflexive) }\end{array}$ & Teleology \\
\hline
\end{tabular}




\begin{tabular}{|c|c|c|c|c|c|c|}
\hline Article & Basic Theory & Framework & Focus & Unit of Change & Mode of Change & $\begin{array}{l}\text { Change } \\
\text { Theory } \\
\end{array}$ \\
\hline Hopwood 1987 & $\begin{array}{l}\text { Multiple theoretical } \\
\text { is sues }\end{array}$ & - & $\begin{array}{l}\text { Diversity of factors } \\
\text { implicated in accounting } \\
\text { change; } \\
\text { Preconditions for } \\
\text { subsequent organisational } \\
\text { changes }\end{array}$ & $\begin{array}{l}\text { Single (insight into the } \\
\text { organisation) }\end{array}$ & $\begin{array}{l}\text { Constructive (accounting } \\
\text { change } \\
\text { can shift the preconditions for } \\
\text { subsequent organisational } \\
\text { changes) }\end{array}$ & Teleology \\
\hline Laughlin 1987 & Critical theory & - & $\begin{array}{l}\text { Social and technical aspects } \\
\text { of societal phenomena in } \\
\text { accounting systems }\end{array}$ & $\begin{array}{l}\text { Single (seeking to understand and } \\
\text { change accounting systems in } \\
\text { organizational contexts) }\end{array}$ & $\begin{array}{l}\text { Constructive (seeking to } \\
\text { understand and change } \\
\text { accounting systems in } \\
\text { organizational contexts) }\end{array}$ & Teleology \\
\hline Louns bury 2008 & & - & $\begin{array}{l}\text { Directions and implications } \\
\text { for the study of accounting } \\
\text { practice; } \\
\text { Institutional and micro- } \\
\text { processual dynamics }\end{array}$ & $\begin{array}{l}\text { Single (conceptual approach to } \\
\text { organizations) }\end{array}$ & $\begin{array}{l}\text { Constructive (how accounting } \\
\text { systems shape and are } \\
\text { shaped by intra-organizational } \\
\text { dynamics) }\end{array}$ & Teleology \\
\hline Jones 2005 & Darwinian theory & Own framework & $\begin{array}{l}\text { Process of replication and } \\
\text { learning }\end{array}$ & $\begin{array}{l}\text { Multiple (process of firm } \\
\text { transformation) }\end{array}$ & $\begin{array}{l}\text { Prescirbed (the role of habits and } \\
\text { routines must be outlined in } \\
\text { specific detail; Unification) }\end{array}$ & Evolution \\
\hline $\begin{array}{l}\text { Jayashree \& } \\
\text { Hussain } 2011\end{array}$ & Balanced score card & Own framework & \begin{tabular}{|l|} 
Focus on deploment of \\
strategic change $=$ change in \\
strategie / new strategic \\
objectives (change process \\
map)
\end{tabular} & Single (changes in organizations) & $\begin{array}{l}\text { Prescirbed (focuses on the } \\
\text { use of formal steps such as } \\
\text { developing change themes and } \\
\text { results, setting change } \\
\text { objectives) }\end{array}$ & Life-Cycle \\
\hline O'Grady et al 2010 & & \begin{tabular}{|l|} 
Viable system \\
model (VSM); \\
Performance \\
management and \\
control \\
framework \\
(PMC); \\
Levers of control \\
(LOC)
\end{tabular} & $\begin{array}{l}\text { VSM: used to assess } \\
\text { frameworks of control; } \\
\text { PMC: } 12 \text { Areas with an } \\
\text { overall scope of management } \\
\text { control (from vision and } \\
\text { mission to operative } \\
\text { questions); } \\
\text { LOC: top down view of } \\
\text { organizational control - focus } \\
\text { on the conrol activities of } \\
\text { senior management - } \\
\text { decisions filter down to all } \\
\text { other organizational levels }\end{array}$ & $\begin{array}{l}\text { Single (management control studies } \\
\text { typically examine how control } \\
\text { systems support the achievement } \\
\text { of organizational objectives) }\end{array}$ & $\begin{array}{l}\text { Constructve (interactions with } \\
\text { the environment, and the } \\
\text { mechanisms for attaining } \\
\text { balance between stability and } \\
\text { change) }\end{array}$ & Teleology \\
\hline Roberts 1994 & $\begin{array}{l}\text { Socio technical } \\
\text { systems design }\end{array}$ & - & $\begin{array}{l}\text { Management accounting } \\
\text { from an organizational } \\
\text { perspective; Change in the } \\
\text { organization design is } \\
\text { reflected in and by the MA } \\
\text { system }\end{array}$ & Single (organizational model) & $\begin{array}{l}\text { Constructive (how the change in } \\
\text { the organization design is } \\
\text { reflected in and by the } \\
\text { management } \\
\text { accounting system) }\end{array}$ & Teleology \\
\hline Sharma et al. 2010 & Institutional theory & - & $\begin{array}{l}\text { Micro-processes and } \\
\text { practice changes around } \\
\text { TQM implementation }\end{array}$ & $\begin{array}{l}\text { Single (a privatized } \\
\text { telecommunication company) }\end{array}$ & \begin{tabular}{|l|} 
Prescribed (introduction of a \\
management control innovation, \\
total quality management \\
techniques to establish new \\
rules)
\end{tabular} & Life-Cycle \\
\hline $\begin{array}{l}\text { ter Bogt \& van } \\
\text { Helden } 2000\end{array}$ & $\begin{array}{l}\text { Institutional theory; } \\
\text { Behavioural theory } \\
\text { of the firm }\end{array}$ & $\begin{array}{l}\text { Combined } \\
\text { framework: } \\
\text { Burns \& Scapens } \\
\text { (2000); Shields \& } \\
\text { Joung (1989); } \\
\text { Cyert \& March } \\
\text { (1963) }\end{array}$ & $\begin{array}{l}\text { Identify and describe the } \\
\text { "development gap" between } \\
\text { the ideal concept of } \\
\text { accounting change and its } \\
\text { ultimate development and the } \\
\text { "usage gap" between the } \\
\text { developed accounting } \\
\text { instruments and their usage } \\
\text { in practice }\end{array}$ & $\begin{array}{l}\text { Single (dutch government, public } \\
\text { administraion) }\end{array}$ & $\begin{array}{l}\text { Prescribed (included actions } \\
\text { based on formal procedures, an } \\
\text { inward-looking organization, a } \\
\text { wait-and-see attitude, and a } \\
\text { citizen-focused approach) }\end{array}$ & Life-Cycle \\
\hline
\end{tabular}

\subsection{Classification of Frameworks and Theories}

As described in the previous paragraph, 19 articles could be found that correspond to the issue of organizational transformation in IT departments. In order to analyze the focus and limitations of existing frameworks, we draw on the work of Van de Ven and Poole (1995). They introduced four basic theories to explain the process of change in organizations: life cycle, teleology, dialectic, and evolution (Van de Ven \& Poole, 1995). The four theories differ regarding the mode of change, which can be prescribed or constructive, and the unit of change, which can be a single or multiple entities. 
Group 1 - Life cycle theory: The life cycle theory depicts the process of change in a single entity as progressing through a necessary sequence of prescribed stages (Van de Ven \& Poole, 1995). Therefore, all frameworks focusing on a single entity and analyzing intended change in the formal management accounting system are assigned to group 1. In total, nine articles met these parameters: Burns and Scapens (2000); Chenhall and Euske (2007); Dambrin et al. (2007); Sharma et al. (2010); ter Bogt and van Helden (2000); Cunningham and Kempling (2009); Applebaum et al. (1998); Jayashree and Hussain (2011); Dillard et al. (2004). Due to their focus on one entity and the prescribed change goals, these frameworks enable a detailed analysis of the effects of planned organizational transformations on the management accounting system (Suddaby et al., 2011; Björck, 2004). Thus, group 1 is considered as highly relevant for the development of a framework for SOEs.

Group 2 - Teleology theory: Similar to the life cycle theory, the teleology theory focuses on a single unit of change. By contrast, the mode of change is not viewed as a prescribed process; rather it emerges through the purposeful social construction among individuals within the entity (Van de Ven \& Poole, 1995). Eight of the 19 articles identified by literature review explain changes in management accounting using a single entity and develop the future state of management accounting changes in a constructive way: Abernethy and Brownell (1999); Ahrens and Chapman (2007); Englund et al. (2011); Hopwood (1987); Laughlin (1987); Lounsbury (2008); Roberts (1994); O'Grady et al. (2010). These articles use interpretive approaches and do not provide a process-oriented framework. Moreover, the integration of environmental effects on organization changes leads to a high and abstract analytical level without the ability to evaluate dynamic processes (Björck 2004), both of which are necessary requirements for analyzing management accounting in SOEs as indicated previously in this chapter. Thus, neither environmental effects nor dynamic processes are considered as a base for the development of an organizational transformation framework on management accounting in SOEs.

Group 3 - Dialectic theory: Unlike the life cycle or teleology theories, the dialectic theory explains the process of organizational development and change in multiple entities. Based on conflicts between entities, a dialectical progression generates this change process (Van de Ven $\&$ Poole, 1995). One literature review article meets these parameters: Baines and Langfield-Smith (2003). This article uses external effects, e.g. market or competitor changes as a starting point for the presented framework; this article cannot be used for analyzing changes in SOEs because external effects are not exposed to the pressure of market forces (Bozeman, 2013). Thus, it seems inappropriate to use the external environment as a starting point for accounting change in SOEs.

Group 4 - Evolution theory: The evolution theory comprises a prescribed sequence of variation, selection, and retention events among entities arising from competition for rare environmental resources (Van de Ven \& Poole, 1995). Thus, it explains change for multiple entities, like the dialectic theory, and proceeds through a continuous cycle to explain strategy making within organizations. The paper presented by Jones (2005) fits this basic theory. However, the multi-entity basis of this theory does not enable the analysis of an organizational transformation and its effect on management accounting because it focuses on 
strategy development. As a result, it misses a detailed representation of management accounting processes inside an organization (Suddaby et al., 2011).

There is high diversity in the approaches regarding the theoretical foundation as well as the level of analysis, ranging from a broad strategic or external perspective to a detailed internal view. Moreover, many different types of frameworks are applied to describe accounting change as a life cycle, teleological, dialectic, or evolutional process. As discussed at the beginning of this section, the four theories differ regarding the mode of change and the unit of change. The combination of these two parameters determines which theory should be applied to explain the change process in the organizational entities.

As the assessment of the four groups shows, only life cycle theories provide an applicable approach for SOEs because their prescribed mode of change with a focus on a single entity coincide with the requirements determined at the beginning of this chapter. However, not all articles included in group 1 present a strong focus on how organizational transformations affect internal processes of the management accounting system. The article by Chenhall and Euske (2007) discusses the role of management control systems in planned organizational change. The framework they apply to analyze the change process does not provide a process perspective, which is one of the core requirements when analyzing management accounting of state-owned enterprises (cf. Suddaby et al., 2011; Björck, 2004). With their article on strategic alignment, Jayashree and Hussain (2011) focus on the usage of integrated and strategic tools throughout the change process. They do not describe the process of organizational transformation and its effects on management accounting. Appelbaum et al. (1998) develop a framework for strategic organizational change. Similar to the contribution of Jayashree and Hussain (2011), they do not provide a detailed perspective on the change process inside the organization but do address external effects as ascendants to organizational change. Also, Appelbaum et al. (1998) do not provide detail as to how management accounting methods should integrated into the legal requirements in a regulated market environment (De Lancer Julnes \& Holzer 2001; Bozeman, 2013). Thus, these three articles of group 1 are excluded from further research. Subsequently, to derive our framework from literature we will focus on the remaining six articles allocated to life cycle theory to further elaborate on management accounting changes in SOEs.

\section{Towards a Framework for Organizational Transformation in IT Departments of SOEs}

\subsection{Deriving Building Blocks for an Organizational Transformation Framework}

To develop an organizational transformation framework, we first summarize the main contributions from our focus literature (s. Table 2). 
Table 2. Main contributions from our focus literature

\begin{tabular}{l|l}
\hline Literature Source & Contribution \\
\hline $\begin{array}{l}\text { Buns and Scapens } \\
(2000):\end{array}$ & $\begin{array}{l}\text { Internal, process-oriented concept of change, based on actions, } \\
\text { rules and routines inside the controlling department }\end{array}$ \\
\hline Dambrin et al. (2007): & $\begin{array}{l}\text { Macro view on the stages of the diffusion process based on } \\
\text { neo-institutional sociology, analyzing ideas, discourses, and } \\
\text { techniques as ascendants of internalization }\end{array}$ \\
\hline Sharma et al. (2010) & $\begin{array}{l}\text { Dynamic perspective on changes and introduction of major } \\
\text { stakeholders in the change process }\end{array}$ \\
\hline ter Bogt and & $\begin{array}{l}\text { Combined framework to illustrate the development gap resulting } \\
\text { from the accounting change process and the usage gap between } \\
\text { newly developed accounting methods and their actual } \\
\text { application }\end{array}$ \\
\hline $\begin{array}{l}\text { Cunningham and } \\
\text { Kempling (2009): }\end{array}$ & $\begin{array}{l}\text { Enumeration and explanation of essential change principles to } \\
\text { assist change in public sector organizations }\end{array}$ \\
\hline Dillard et al. (2004): & $\begin{array}{l}\text { Three-level framework encompassing economic and political } \\
\text { levels, organizational field level down to the organizational level } \\
\text { to analyze levels of social, political, and economic issues }\end{array}$ \\
\hline
\end{tabular}

To assess the applicability of the above contributions in an SOE environment, we then reviewed to what extent these contributions comply with the characteristics of organizational transformation in SOEs as described in section 2.1 of this paper. We differentiated the degree of compliance using three levels. Articles that comprehensively explain a requirement and explicitly implement it into the framework are classified as a "match". If articles briefly consider a requirement but do not incorporate it into the framework they are classified as a "partial match". Those articles that do not consider the requirement concerned are classified "no match".

The first requirement to be considered with management accounting change in SOEs characterizes the need for dynamic process incorporation in management accounting of SOEs. The concept of Burns and Scapens (2000) analyzes accounting change as a dynamic process (ter Bogt \& van Helden, 2000). This also applies to the framework of Sharma et al. (2010), which enables a dynamic representation of the institutionalization process. Regarding the dynamic process requirement, Dillard et al. (2004) visualize the institutionalization process in a recursive way. Thus, these three papers are classified as "match" with this requirement.

Stakeholder integration is the second requirement that must be taken into account in the change of management accounting in SOEs. Two articles comply with this requirement. Although they do not provide a detailed process-oriented framework, Cunningham and Kempling (2010) consider public stakeholders as relevant factors in their change principles. Sharma et al. (2010) integrate the stakeholder perspective explicitly into their framework. By recognizing higher levels of social, political and economic issues, Dillard et al. (Dillard et al., 2004) provide a platform for stakeholders, although they do not explicitly incorporate them into their framework. Thus, we classify their framework as a "partial match".

The third requirement deals with the detailed representation of the change process. One framework complies with this requirement: Burns and Scapens (2000) explain the change process on a detailed organizational level (Dillard et al., 2004). The framework of Dambrin et al. (2007) recognizes higher levels of social, political, and economic issues and provides a 
platform for stakeholders; however, these authors do not explicitly incorporate these issues into their framework. In general, the framework of Dambrin et al. (2007) was developed on a macro level and does not consider the dynamics in the process of accounting change or public characteristics. Thus, their framework is a "partial match" with the third requirement. The goal of the framework by ter Bogt and van Helden (2000) is to identify a development and usage gap in management accounting. Yet, their framework fails to capture the dynamic and detailed perspective of Burns and Scapens, which they use as a basis for their framework. Hence, the framework developed by ter Bogt and van Helden does not match this requirement.

The requirement to consider the attitudes of public employees is mentioned twice in the selected articles. Ter Bogt and van Helden (2000), whose framework is designed for management accounting change in government, consider the characteristics of public employees when analyzing the change process. However, they do not implement specific elements into their framework to depict these characteristics; their framework is thus classified as a "partial match". Cunningham and Kempling (2010) explicitly focus on the characteristics of public sector organizations in their article, and consequently on public employees, when determining their change principles. Thus, they fully match this requirement.

Table 3. Requirement-based evaluation of existing frameworks

\begin{tabular}{|c|c|c|c|c|}
\hline \multirow[b]{2}{*}{ Existing frameworks } & \multicolumn{4}{|c|}{ Management Accounting Requirements of SOFs } \\
\hline & $\begin{array}{l}\text { 1) Dynamic Process } \\
\text { Incorporation }\end{array}$ & $\begin{array}{l}\text { 2) Stakeholder } \\
\text { Integration }\end{array}$ & $\begin{array}{l}\text { 3) Detailed Rep- } \\
\text { resentation }\end{array}$ & $\begin{array}{l}\text { 4) Consideration of } \\
\text { Public Employees }\end{array}$ \\
\hline ter Bogt and van Helden (2000) & - & - & - & (o) \\
\hline Burns and Scapens (2000) & $\mathbf{X}$ & - & $\mathbf{X}$ & - \\
\hline Dambrin et al. (2007) & - & - & (o) & - \\
\hline Cunningham and Kempling (2009) & - & - & - & $\mathbf{X}$ \\
\hline Dillard et al. (2004) & (o) & (o) & - & - \\
\hline Sharma et al. (2010) & $\mathbf{X}$ & $\mathbf{X}$ & - & - \\
\hline Key: & $\begin{aligned} \mathbf{X} & =\text { Matches with th } \\
(\mathrm{o}) & =\text { Partial Match w } \\
- & =\text { No Match with }\end{aligned}$ & $\begin{array}{l}\text { Requirement } \\
\text { the Requirement } \\
\text { Requirement }\end{array}$ & & \\
\hline
\end{tabular}

Table 3 summarizes the findings of the requirement-based evaluation of existing frameworks and shows the lack of an appropriate conceptual framework for organizational transformations in SOEs. Thus, none of the existing frameworks meets all four requirements of management accounting change in SOEs. Three of six frameworks fully match two requirements of SOEs. This leads to the selection of the following three articles as basic elements of the conceptual framework for management accounting change in SOEs: Burns and Scapens (2000), Cunningham and Kempling (2009) and Sharma et al. (2010). 


\subsection{Organizational Transformation Framework for IT Departments in SOEs}

To include the above contributions into our framework, we use the punctuated equilibrium model for organizational change (cf. Tushman \& O'Reilly, 1996). Using this model, the elements of each framework are assigned to the basic states of organizational change according to the punctuated equilibrium model. The punctuated equilibrium model proposes two states (cf. Gersick, 1991; Sabherwal et al., 2001). One state consists of a long phase of stability, called the equilibrium. It is characterized by persistent structures and only small and incremental changes inside the organization. The second state describes short periods of revolution, the 'punctuations', fundamentally alter underlying structures and cause qualitative changes.

The equilibrium in Burns and Scapens' (2000) framework is represented by the institutions with defined rules and routines as well as by specified actions, illustrated by the black outlined rectangles in Figure 2. The framework of Sharma et al. (2010) also contains institution as an element to incorporate the state of persistent structures. The state of fundamental change according to Burns and Scapens (2000) is comprised via process reproduction as well as institutionalization, which form the transition into the new institution. Sharma et al. (2010) use the element 'uncertainty' for this state. The change principles presented by Cunningham and Kempling (2009) also depict the transition phase of a public organization with qualitative changes and, therefore, are assigned to the revolutionary state. In the following, all elements of the three frameworks are integrated according to the states of the punctuated equilibrium model. The new framework will provide an internally consistent illustration of organizational transformations. Based on the characteristics of organizational transformation in IT departments of SOEs, the framework (see Figure 2) embodies the dynamic process model for accounting change according to Burns and Scapens (2000). The model encompasses four basic elements: the institutional realm, routines, rules, and the realm of action.

The institutional realm comprises assumptions and habits that govern organizational activities and relationships of the actors. Rules include specific procedures and formal descriptions of the management accounting system. Routines, however, represent the currently applied management accounting methods based on the management accounting system. The realm of action follows the specified organizational conditions set by the institutional realm, rules, and routines and refers to the execution of management accounting methods.

Based on this, the conceptual model with its interaction between the four elements is being expanded by the integration of external change stakeholders (see Table 3), which is an indispensable requirement for public organizations. These stakeholders are characterized by 1) not being members of the change unit, and 2) having a decisive role regarding the mode of change. They are integrated in the new framework according to the model of Sharma et al. (2010) who identified the interactions between involved external change stakeholders and institutions. There are three types of external change stakeholders that should be differentiated: change agent, external stakeholders, and change manager.

The change agent, as strategic stakeholder, is interested in organizational transformations and 
can leverage resources to create new institutions or to convert existing ones (Maguire et al. 2004). Possible triggers for organizational change may arise from contradictions of the existing institution or from external stakeholders, e.g., through changes in customer requirements or political interests, and are taken up by the change agent. According to the triggers, the change manager can destroy prior institutional occurrence and may give rise to some uncertainty due to the undefined transition status (Sharma et al., 2010).

After integrating the basic model of Burns and Scapens (2000) with the external change stakeholders according Sharma et al. (2010), we then assign the nine assisting change principles as evinced by Cunningham and Kempling (2009) in the model to consider attitude and commitment of public employees.

First, the change agent should establish the need for change (1). Together with external stakeholders and the change manager, the change agent forms the guiding coalition (2), which is a committed leadership team representing the informal organization, gathering information and conducting adjustments during the change process (Cunningham \& Kempling, 2009). The guiding coalition develops a commitment plan (3) and defines communication compliance during the change process. The framework is supplemented by four further change principles to enhance the public perspective in the model. The definition of reorganization goals (4) and continuous improvement throughout the project (6) are also affiliated to the manager. The remaining principles focus on the adjustment of operative structures in the organization (7) and the encouragement of the employees to execute new actions (8). The role of the change manager is an operative one, responsible for recognizing as well as responding to resistances (5) in the change process and implementing new rules and routines (9) through the institutional domain into the transformed organization (Sharma et al., 2010).

Thus, all requirements of management accounting in SOEs are implemented by the framework (Figure 2). Between the two institutional states (initial institution and new institution after the change process), some uncertainty may arise from the deinstitutionalization during the transformation process amongst organizational actors (Sharma et al., 2010). The elements displayed using dotted-lines identify the revolutionary transition phase (cf. punctuated equilibrium model). Figure 2 presents the framework which contains all elements for an organizational transformation framework to be applied in the SOE domain. The arrows represent likely interactions among organizational elements and change stakeholders, not causation between those. The elements marked with a '*' represent the new equilibrium of the organization incorporated by its institutional realm, rules, routines and actions. 


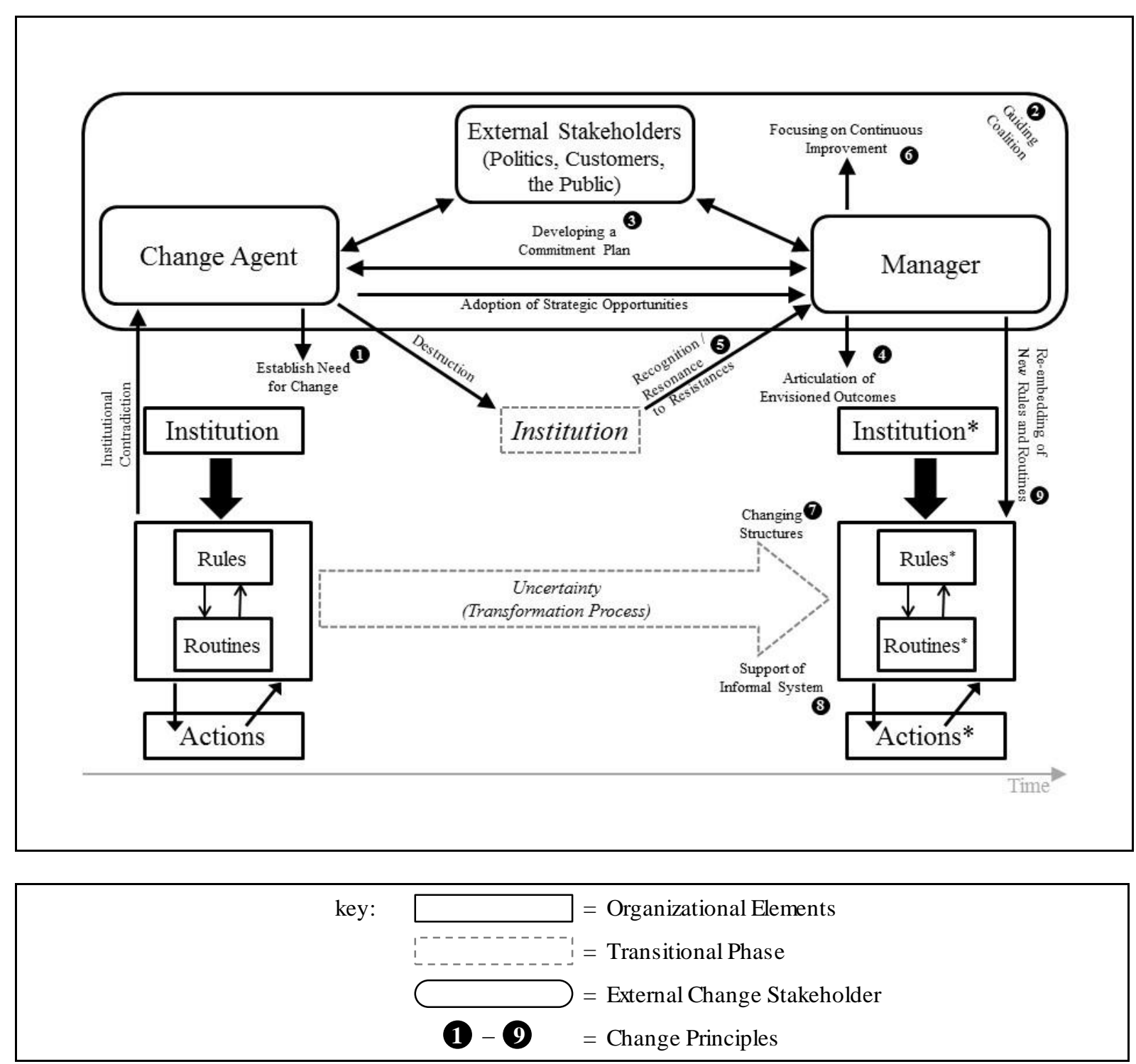

Figure 2. A framework for organizational transformation in IT departments of SOEs

\section{A Case Study on Management Accounting Change in IT Departments}

\subsection{Research Design}

Having derived our framework for organizational transformation in IT departments of SOEs, we next apply the framework in a single case study. We chose an exploratory qualitative research approach to conduct this study because an in-depth understanding of factors that cause or overcome transformation barriers in IT departments of state-owned enterprises is required to apply the developed framework. In line with this goal, semi-structured interviews allow the interviewees to answer freely instead of choosing predefined answers from a list (Myers \& Newman, 2007). Semi-open questions also help to collect additional and possibly hidden information and, moreover, provide the flexibility to ask targeted inquiries during the interviews (Myers \& Newman, 2007).

The following case study draws on the recommendations of Dubé and Paré (2003) and Paré (2004) for case study research. Case study research is clearly useful when a natural setting 
and contemporary events are in focus (Benbasat et al., 1987), which applies in this research. A single case study is appropriate in this context as it contributes to testing the capabilities of a framework (Yin, 2008).

We selected a German airport that is majority-owned by a German federal government. Some of the supervisory board members of this airport are politicians. The focus of this study draws on ERP system introduction and business process redesign activities in the IT department. What made the case especially intriguing for our research is that the airport outsourced its IT department several years ago to a joint venture subsidiary together with a company leading in the field of the introduction of a new ERP system and business processes. Thus, the case study partners had in-depth experience in the field of changes in IT management and re-design of business processes.

\subsection{Data Collection and Analysis}

A semi-structured interview was used as the primary tool for data collection. To answer the applicability of the framework, a questionnaire was developed covering two main areas. In the first part, the structure of the company, the management accounting tools and processes used as well as the procedure and the experiences of the outsourcing process, was queried. The second part focused on identifying success and failure factors as well as challenges and requirements for the management of the IT department.

In total, we conducted 10 interviews with five interview partners. The interview sessions took place in 2012, 2014 and 2017. The interview partners were: the vice president IT financial management (I1 / 2014 / 2 interviews), head of information management (I2 / 2012, 2017 / 2 interviews), senior vice president corporate IT (I3 / 2014 / 4 interviews), vice president corporate financial management (I4 / 2014 / 1 interview), and manager corporate IT accounting (I5 / 2017 / 1 interview). All interviews were done face-to-face. The professional experience of the interviewees ranged from 5 to 30 years. The interviewees held different jobs in their organization. The interviews lasted between 45 minutes and 2.0 hours and the interview language was German for all interviews.

The decisive factors for selecting the interviewees was comprehensive experience regarding the entire outsourcing process, possession of fundamental knowledge in the field of IT management accounting, and the ability to describe changes in the IT department from a general perspective. This focused approach essentially follows the characteristics of the homogeneous sampling of Patton (2002). In terms of content, the interviews covered the timeframe before project begin until now. Thus, the state of the ERP system and business processes before and after as well as the change process can be captured.

We analyzed the interviews using qualitative analysis techniques. All expert interviews were tape-recorded and transcribed afterwards. To evaluate the information from the interviews systematically, the interviews were coded in a spreadsheet data base according to the guidelines of qualitative content analysis by Mayring (2009). For this, a summary of the content of the statements based on the literal statements was prepared. Then three coding elements were introduced. The first coding element determines whether the temporal relation 
of the statement lies before or after the outsourcing. The second coding element is used to extract the controlling instrument within the statement. The third element serves to assign the statement to the model we have designed. In addition, a coding element was used to identify success or failure actors. The quotations cited in this paper were translated into English by the authors and cross-checked by an English language editor.

As the final step in our analysis of data, the information of the coding elements (time period, management accounting tool, etc.) is transmitted into the framework. Table 4 presents an excerpt of the coding table.

Table 4. Extract from the coding table with interview data

\begin{tabular}{|c|c|c|c|c|c|c|}
\hline$\#$ & Question & Answer (lite rally) & $\begin{array}{l}\text { Before / After } \\
\text { Outsourcing }\end{array}$ & $\begin{array}{l}\text { Management } \\
\text { Accounting Tool }\end{array}$ & $\begin{array}{l}\text { Reference to the } \\
\text { Frame work }\end{array}$ & $\begin{array}{l}\text { Success / } \\
\text { Failure Factor }\end{array}$ \\
\hline 2.4 & $\begin{array}{l}\text { What arguments / } \\
\text { decisions have led to use } \\
\text { the actual tools? }\end{array}$ & $\begin{array}{l}\text { The focus is on the operating business, it has to } \\
\text { work. A profit center accounting did not exist } \\
\text { and it was not tracked either. I think profit center } \\
\text { accounting fits good, but it was not performed. } \\
\text { Both, the coporate management accounting and } \\
\text { board of directors, have no IT affinity. IT is still } \\
\text { seen as a black box and a big cost factor, but not } \\
\text { as a business enabler. }\end{array}$ & Before and after & - & Institutional level & $\begin{array}{l}\text { Failure factor: no } \\
\text { management } \\
\text { attention of affinity } \\
\text { to IT; IT is not seen } \\
\text { as possible business } \\
\text { process enabler }\end{array}$ \\
\hline 2.5 & $\begin{array}{l}\text { Regarding transparancy, } \\
\text { which management } \\
\text { accounting tools do you } \\
\text { use? }\end{array}$ & $\begin{array}{l}\text { Yes, we use internal charging. That has to do } \\
\text { with cost-sensitive assignment of } 100 \% \text { of the } \\
\text { potentiall hours to individual products. } \\
\text { Furthermore, there is a ticket system but it does } \\
\text { not distinguish between incident and change. It all } \\
\text { comes together and that is difficult. An estimate } \\
\text { is better than nothing. But the insight is missing. }\end{array}$ & Before and after & $\begin{array}{l}\text { hour charging; } \\
\text { Ticket system; }\end{array}$ & $\begin{array}{l}\text { Routines; } \\
\text { Actions }\end{array}$ & $\begin{array}{l}\text { Success / failor } \\
\text { factor: coach the } \\
\text { employess on KPIs; } \\
\text { Try to allocate as } \\
\text { realistic as possible } \\
\text { (no } 100 \% \text { cost } \\
\text { allocation) }\end{array}$ \\
\hline
\end{tabular}

Additional information from both internal and external sources was searched and analyzed to triangulate the results. This encompasses organization charts, business reports and service descriptions. The information was used to better understand the statements of the interview partners regarding the four subject areas mentioned above.

\subsection{Application of Our Framework to the Case}

At first, the unit of change and mode of change determined by Van de Ven and Poole (1995) must be assessed to determine if they apply to the process-oriented concept of the framework. In this case the unit of change is the management accounting unit of the IT department (part of the overall IT department), thus it is a single entity. Based on the data from the case study, the mode of change complies with the prescribed change mode as the change was initiated in order to incrementally transfer the internal IT department into a new IT subsidiary. Thus, according to Van de Ven and Poole (1995) it is a life-cycle or stage-based change and is compliant to the process-oriented concept of the framework.

The new ERP system introduction project started in 2002 with an outsourcing project. The initial goal of the outsourcing project was to additionally offer IT solutions to the regional market to reduce operational cost by economies of scale and to generate contribution margins with additional external revenues. Interviewee I1 explains the cost structure of the company:

Our experience shows that 40 percent of our costs are directly sales-related costs. 60 percent are overhead; overhead costs are usually higher. 
In order to reduce overhead costs, the company's own IT department has become a new joint venture subsidiary, which was founded together with a private operating company. This joint venture company is partial owned by the airport and, consequently, also a SOE. The IT subsidiary is responsible for running the IT infrastructure and applications for the airport operator. To concentrate the corporate IT control, a new organizational unit inside the parent company (called information management [IM]), was founded. The purpose of IM is to make decisions on a strategic level with regards to IT management accounting. IM serves as a communication link between the airport operator and any external IT service provider. From the parent company side, IM should be the main contractor for IT products and services. Hence, the business units of the airport made decisions directly with the IT service provider in many cases. An IT contract was signed at the beginning of the outsourcing process. This contract does not contain a service level agreement (SLA) and it has been infrequently updated since the beginning of the IT outsourcing, as the interviewee I 2 describes:

Yes, 10 years ago, a contract was made with them [the founded joint venture IT subsidiary]. The contract defines services and prices but no real service levels, just reaction times, what is legitimate for subsidiaries. The contract was reviewed from time to time, but it was not revised carefully.

According to I2, there is a lack of a working contract management. Contributing to this problem are the following factors: a missing service monitoring in the IT management accounting departments of both companies, a lack of quality measures and SLAs in the outsourcing contract, and missing updates of the contract documentation. I2s explanation for the inadequate contract management refers to the fact that the IT provider is a subsidiary of the airport. Further reasons for the inadequate contract management include the layoff in the management level of the IT service provider after the outsourcing process and the failed attempt to sell IT products in the regional market.

The employees of the IT service provider have a conservative attitude and tend to refuse organizational changes in business structures. Furthermore, the IT organization lacks sufficient qualified employees, as I3 reports. There are special IT applications for which employees lack the appropriate experience and know how. I2 suggested hiring a consultant to temporary help solve a specific problem efficiently. However, this was not possible as the management did not agree on an additional budget to support this suggestion. I 2 provides the following example:

The budget is too small, otherwise I would hire management accounting consultants. However, there is a lack of understanding in the company. I'm confident if I go into the executive board and apply for 100,000 Euros for implementing a new IT governance concept, they would not authorize it.

Moreover, not just the employees but also management is conservative and has no apparent desire or willingness to change to accommodate innovations. The management level of the IT service provider is concerned with lowering total costs as not to exceed the budget allocated to them by the parent company. Due to this strong focus on total cost reduction and the missing competition with other market participants, there is little or no impulse to change or 
be innovative.

There is also a lack of a clear IT strategy and governance. I2 explains that the business units can request new software as they like - without considering the corporate IT strategy. The airport operator has no binding IT governance; for example, how to proceed in the case of purchasing new software and replacing outdated software. Another example for the missing IT governance is the role conflict between IM and the executive board. On the one hand, IM is responsible for harmonizing the IT portfolio by, for example, getting rid of redundant or inefficient applications. On the other hand, the board of executives is responsible for the budget. However, the board does not provide additional budget for IT standardization projects. Looking at IT management accounting tools, the airport strategic tool can provide a clear definition of goals. There are some tools available for measuring the technical performance (availability or stability of IT systems), but there is no roadmap that shows the strategic IT components and landscape for the next couple of years.

I2 explains that the company did not think about defined and working IT processes before initiation of the IT outsourcing. This should concern all organizational processes affected by IT products or services. After defining these processes, the company needs to decide which processes are going to be outsourced. It is important to outsource entire processes with limited organizational interfaces. Because the organization of the airport is still functionally organized and not based on processes, it was very difficult to outsource processes that run through the whole organization, for example the IT purchasing process. Because the IT subsidiary is completely owned by the operator and the corporate business units had to purchase their IT services from the corporate IT provider, there was no need for the IT managers to try to better understand the challenges arising in the business units. According to I4, in comparison to the IT subsidiary, an external service provider can contribute several benefits:

The main tasks of an external service provider are of course the provision of a functioning IT environment and a high degree of standardization. The external service provider should contribute know-how and experience to innovate and to monitor the IT market regularly.

Looking back at the outsourcing process, I5 critically notes that in 2017 the tools and procedures in IT management accounting are still on a low level, although one goal of the outsourcing process was to improve transparency regarding e.g. the costs of service delivery. As the airport is a SOE providing infrastructural services of general interest and does not directly experience competition due to its local monopoly, the pressure from its public shareholders to improve efficiency and innovative power is minimal. However, structural changes in the aviation industry and the withdrawal of the public shareholders to provide further financial resources led to a change in corporate governance. Thus, the airport business divisions were set up as profit centers and pursue economic objectives. This led to a critical perspective on all internal services, including IT services. From the specification of minimal area cost, an extensive internal service accounting via cost center reports and charging per project hours was developed. Based on the idea of the shareholders to lower IT costs by generating external revenues in the regional market, the executive board decided to outsource 
the IT department into a joint venture subsidiary.

Without considering the IM unit, the executive board tried to set up a new market strategy and commitment plan with the newly hired IT subsidiary management. This organizational and personnel situation was obstructive for building up a guiding coalition. Furthermore, the executive board persisted with their objective to lower total IT costs. Because of those strict budget regulations, the new IT management could not meet with the commitment plan as well as the initial goal of winning new customers in the regional market.

To avoid additional discussions with the works council and follow a course of least resistance, the executive board transferred the existing organizational structure of the IT department without modification into the IT subsidiary and offered job guarantees to all IT employees. Without making necessary changes in the organizational or informal structure the new IT management could not implement new rules and routines which has been inherited of the former parent company and was therefore forced to maintain the existing ones. As the initial goal was dropped, the institutional routines did not change from those found in the former IT department. The idea of low IT costs resulted in a continuous reduction of IT-budget for the IT subsidiary. Figure 3 summarizes the results of the application of the framework for organizational change in IT departments of SOEs.

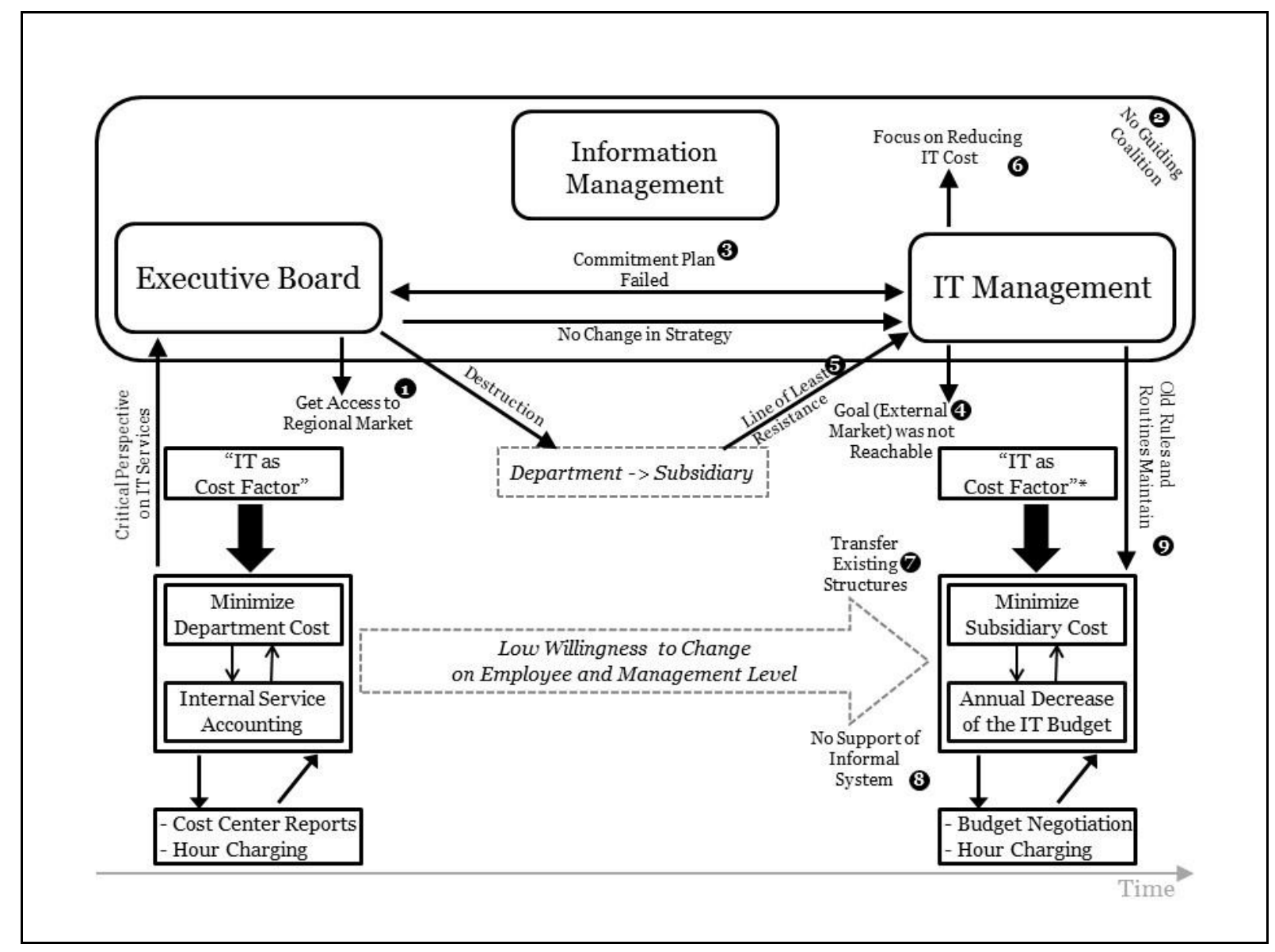

Figure 3. Transformation process of management accounting in the IT department 


\section{Findings and Discussion}

Our findings from the literature review show the lack of an appropriate conceptual framework for organizational transformations in SOEs. None of the existing frameworks meets all four requirements of management accounting change in SOEs. With our research we can close this research gap by providing a framework to systematically identify transformation barriers in SOEs.

The previous section provides an example for management accounting change in SOEs. As the case shows, the rules and routines with the introduction of the new ERP system did not change after the outsourcing process, although the parent company tried to set up a new, competitive IT subsidiary. The framework enables systematic insights into the change process and helps to identify some transformation barriers that we will discuss below.

As the framework shows, the initial need for change seems appropriate. That is, the idea of the executive board to set up an IT subsidiary with external customers to improve the cost situation and product innovation for the existing business units of the airport. But there was no consistent connection of the initial need for change from the organizational unit to all stakeholders at the management level. One example of this is represented in the framework by the lack of arrows to the change stakeholder "information management", which was not involved in the change process by the other change stakeholders. Therefore, in the framework the change trigger can be observed along the transformation, starting with the institutional situation (critical perspective on IT services) to the stakeholder level (executive board) and the associated change principle, incorporating the need for change (get access to regional market). The three basic concepts of Burns \& Scapens (2000), Sharma et al. (2010), and Cunningham \& Kempling (2009) solely would not provide this insight systematically on their own.

Further insight can be drawn from the connections inside the guiding coalition. In addition to the three change stakeholders (change agent, external stakeholders and manager) the guiding coalition consists of two linking change attributes: development of the commitment plan and adoption of strategic change opportunities. In contrast to the existing frameworks by Sharma et al. (2010) and Cunningham and Kempling (2009), the framework we propose integrates the aspects of the linking change attributes. Hence, the framework is able to analyze reasons for stable or loose guiding coalitions, as the practical example reveals.

The initial idea of a strategic change in IT and the associated commitment plan suffered when the IT management had to reduce overall IT costs. The guiding coalition, including the executive board, did not adequately respond to this situation. Moreover, at the end of the change process, combining the three basic models via the framework enables the analysis of the unsuccessful implementation of new IT management accounting tools. One reason for this unsuccessful implementation is the unmodified transformation of the existing IT department structure into the IT subsidiary (change principle). Another reason can be found in the loss of the initial change trigger and the strong focus of reducing cost in the IT subsidiary (change participants). Thus, because of the unchanged structures and the unchanged institutional background, the IT management could not implement new IT 
management accounting tools such as qualitative measures or SLA monitoring (organizational elements).

In addition to the previously mentioned change principles according Cunningham and Kempling (2009) in the framework, the lack of support of the informal system in terms of too little time taken to coach the employees and not keeping track of staff competencies lead to invisible resistance in the change process on the organizational level. As the discussion shows, the framework enables a systematic and in-depth analysis of the change process by combining three basic accounting change concepts.

Our framework helps to identify two empirical transformation barriers. One transformation barrier affects employees. As the framework shows, the employees' needs were not considered in the change process. The executive management followed the path of least resistance and did not change the organizational structure. Furthermore, there was no influence of the leadership team on the informal system via coaching or individual conversations. The employees were not introduced to the new IT strategy, which offered them potential benefits. Hence, it would have been supportive to entrust the employees with more challenging and responsible tasks such as contract management instead of cost center accounting.

The second transformation barrier is derived from the framework and concerns the external change stakeholders. The framework reveals the missing integration of IM into the change process. IM was not able to implement an adapted IT governance concept. The decoupling of competencies between all three change participants in this case would have been helpful to reliably bind them with the commitment plan and to form a stable guiding coalition.

These two insights were very helpful for the further development of the founded IT subsidiary. In 2016, parts of the IT subsidiary were sold to another service provider. During this organizational transformation, the findings from the first outsourcing phase were given special attention, as confirmed by two interviewees in the 2017 interviews. Thus, the outsourcing could be supported with good conditions for economic success and stable business development in the coming years.

As our literature review shows, different basic theories to describe the process of change in organizations have been applied so far. However, only frameworks using life cycle theory as a basic theory are compatible with SOEs as they focus on a single entity and enable a detailed analysis of the effects on the management accounting system arising from planned organizational transformations. By assessing the remaining articles with the management accounting requirements of public organizations, we determined that none of the articles comprise all four requirements of management accounting change in SOEs.

Finally, our framework enables a systematic analysis of the organizational transformation along the change process. The comparison of the practical case shown in the framework with the initial framework (Figure 2) reveals two empirical transformation barriers which were not identified by the company's experts during the interviews. Thus, the new framework for management accounting change in IT departments of SOEs can determine additional insights 
from organizational transformations.

Applying the framework to further case studies will help researchers and practitioners to better understand if factors exist in SOEs but not in private companies that influence organizational change projects. As we performed a single case study in this paper, additional case studies might be useful to further explore and verify our results. Researchers might target countries other than Germany for further validation of our framework.

\section{Conclusion}

This contribution extends research on organizational transformations and SOEs. We developed a new framework by building on three existing models via the punctuated equilibrium model, which enables a systematic insight into the organizational transformation of management accounting in SOEs. Underlying major aspects of the new framework include its dynamic process incorporation, explicit stakeholder integration, a detailed representation of the change process, and the consideration of the characteristics of public employees. Thus, our framework represents a holistic consideration of all four requirements on introducing new ERP systems and business processes in IT departments of SOEs. We applied our new framework to a case study and showed that the framework can identify transformation barriers which were initially hidden to the managers involved in the change process (e.g., required change of organizational structures, required change of SLAs).

For researchers, we provide a framework to analyze the effects of organizational transformations when introducing new ERP systems and business processes in IT departments of SOEs. For practitioners, this framework can become a valuable tool to actively shape the organizational transformation in their IT department. Insights of our framework can help practitioners to enable successful organizational transformations, as our case study shows in retrospect.

\section{References}

Abernethy, M., \& Brownell, P. (1999). The role of budgets in organizations facing strategic change: an exploratory study. Accounting Organizations and Society, 24(3), 189-204. https://doi.org/10.1016/S0361-3682(98)00059-2

Ackoff, R. L. (2006). Idealized Design: How to Dissolve Tomorrow's Crisis...Today. Philadelphia, PA: Wharton School Publishing.

Ahrens, T., \& Chapman, C. (2007). Management accounting as practice. Accounting Organizations and Society, 32(1), 1-27. https://doi.org/10.1016/j.aos.2006.09.013

Al-Haddad, S., \& Kotnour, T. (2015). Integrating the organizational change literature: a model for successful change. Journal of Organizational Change Management, 28(2), 234-262. https://doi.org/10.1108/JOCM-11-2013-0215

Applebaum, S. H., St-Pierre, N., \& Glavas, W. (1998). Strategic organizational change: the role of leadership, learning, motivation and productivity. Management Decision, 36(5), 289-301. https://doi.org/10.1108/00251749810220496 
Baines, A., \& Langfield, S. K. (2003). Antecedents to management accounting change: a structural equation approach. Accounting Organizations and Society, 28(7-8), 675-698. https://doi.org/10.1016/S0361-3682(02)00102-2

Balogun, J., \& Hope, H. V. (2004). Exploring Strategic Change. London, UK: Prentice Hall.

Beer, M., \& Nohria, N. (2000). Cracking the code of change. Harvard Business Review, 78(3), 133-141.

Benbasat, I., Goldstein, D. K., \& Mead, M. (1987). The Case Research Strategy in Studies of Information Systems. MIS Quarterly, 11(3), 369-386. https://doi.org/10.2307/248684

Björck, F. (2004). Institutional Theory: A New Perspective for Research into IS/IT Security in Organisations. Proceedings of the 37th Annual Hawaii International Conference on System Sciences HICSS, Hawaii. https://doi.org/10.1109/HICSS.2004.1265444

Bogt, H. J., \& van Helden, G. J. (2000). Accounting change in Dutch government: Exploring the gap between expectations and realizations. Management Accounting Research, 11(2), 675-698. https://doi.org/10.1006/mare.2000.0132

Boubakria, N., Cosset, J. C., \& Saffar, W. (2008). Political connections of newly privatized firms. Journal of Corporate Finance, 14(5), 654-673. https://doi.org/10.1016/j.jcorpfin.2008.08.003

Boyne, G. (2002). Public and Private Management: What is the difference? Journal of Management Studies, 39(1), 97-122. https://doi.org/10.1111/1467-6486.00284

Bozeman, B. (2013). What Organization Theorists and Public Policy Researchers Can Learn from One Another: Publicness Theory as a Case-in-Point. Organization Studies, 34(2), 169-188. https://doi.org/10.1177/0170840612473549

Burnes, B. (2004). Managing Change: A Strategic Approach to Organizational Dynamics. Harlow: Prentice Hall.

Burns, J., \& Scapens, R. W. (2000). Conceptualizing management accounting change: an institutional framework. Management Accounting Research, 11(1), 3-25. https://doi.org/10.1006/mare.1999.0119

Chenhall, R., \& Euske, K. (2007). The role of management control systems in planned organizational change: An analysis of two organizations. Accounting Organizations and Society, 32(7-8), 601-637. https://doi.org/10.1016/j.aos.2006.09.007

Cooper, H. M. (1989). Organizing knowledge synthesis: A taxonomy of literature reviews. Knowledge in Society, 1, 104-126. https://doi.org/10.1007/BF03177550

Cordella, A., \& Bonina, C. (2012). A public value perspective for ICT enabled public sector reforms: A theoretical reflection. Government Information Quarterly, 29(4), 512-520. https://doi.org/10.1016/j.giq.2012.03.004 


\section{Macrothink}

Journal of Public Administration and Governance ISSN 2161-7104 2018, Vol. 8, No. 1

Cordella, A., \& Tempini, N. (2015). E-government and organizational change: Reappraising the role of ICT and bureaucracy in public service delivery. Government Information Quarterly, 32(3), 279-286. https://doi.org/10.1016/j.giq.2015.03.005

Cordella, A., \& Willcocks, L. (2012). Government policy, public value and IT outsourcing: The strategic case of ASPIRE. The Journal of Strategic Information Systems, 21(4), 295-307. https://doi.org/10.1016/j.jsis.2012.10.007

Cunningham, J. B., \& Kempling, J. (2009). Implementing change in public sector organizations. Management $\quad$ Decision, 330-334. https://doi.org/10.1108/00251740910938948

Da Cruz, N. F., \& Marques, R. C. (2012). Mixed Companies and Local Governance: No Man Can Serve Two Masters. Public Administration, 90(3), 737-758. https://doi.org/10.1111/j.1467-9299.2011.02020.x

Damanpour, F., Magelssen, C., \& Chiu, H. H. (2013). Outsourcing and Insourcing Organizational Services: Operational Capabilities \& Strategy Recurrence. Academy of Management Proceedings, 2013(1),

13137. https://doi.org/10.5465/AMBPP.2013.13137abstract

Dambrin, C., Lambert, C., \& Sponem, S. (2007). Control and change - Analysing the process of institutionalization. Management Accounting Research, 18(2), 172-208. https://doi.org/10.1016/j.mar.2007.02.003

De Lancer, J. P., \& Holzer, M. (2001). Promoting the Utilization of Performance Measures in Public Organizations: An Empirical Study of Factors Affecting Adoption and Implementation. Public Administration Review, 61(6), 693-708. https://doi.org/10.1111/0033-3352.00140

Dillard, J., Rigsby, J., \& Goodman, C. (2004). The making and remaking of organization context: Duality and the institutionalization process. Accounting, Auditing \& Accountability Journal, 17(4), 506-542. https://doi.org/10.1108/09513570410554542

Dubé, L., \& Paré, G. (2003). Rigor in Information Systems Positivist Case Research - Current Practices, Trends, and Recommendations. MIS Quarterly, 27(4), 597-635. https://doi.org/10.2307/30036550

Englund, H., Gerdin, J., \& Burns, J. (2011). 25 Years of Giddens in accounting research: Achievements, limitations and the future. Accounting Organizations and Society, 36(8), 494-513. https://doi.org/10.1016/j.aos.2011.10.001

Ertl, C., Greger, V., Wolf, P., \& Krcmar, H. (2014). Organizational Forms and Their Effect on Performance Management of IT. Proceedings of the 14th European Conference on eGovernment ECEG, Brasov, 85-92.

Gersick, C. (1991). Revolutionary Change Theories: A multiple exploration of the punctuated equilibrium model. Academy of Management Review, 16(1), 10-36. https://doi.org/10.5465/AMR.1991.4278988 
Gong, Y., \& Janssen, M. (2012). From policy implementation to business process management: Principles for creating flexibility and agility. Government Information Quarterly, 29(s1), 61-71. https://doi.org/10.1016/j.giq.2011.08.004

Haahr, L. (2014). Wrestling with Contradictions in Government Social Media Practices. International Journal of Electronic Government Research, 10(1), 35-45. https://doi.org/10.4018/ijegr.2014010103

Hopwood, A. (1987). The archeology of accounting systems. Accounting Organizations and Society, 12(3), 207-234. https://doi.org/10.1016/0361-3682(87)90038-9

Jacobs, G., van Witteloostuijn, A. \& Christe, Z. J. (2013). A theoretical framework of organizational change. Journal of Organizational Change Management, 26(5), 772-792. https://doi.org/10.1108/JOCM-09-2012-0137

Jansson, N. (2013). Organizational change as practice: a critical analysis. Journal of Organizational Change Management, 26(6), 1003-1019. https://doi.org/10.1108/JOCM-09-2012-0152

Jayashree, P., \& Hussain, S. J. (2011). Aligning change deployment: a Balanced Scorecard approach. Measuring Business Excellence, 15(3), 63-85. https://doi.org/10.1108/13683041111161166

Joha, A., \& Janssen, M. (2010). Public-private partnerships, outsourcing or shared service centers?: Motives and intents for selecting sourcing configurations. Transforming Government: People, Process and Policy, 4(3), 232-248. https://doi.org/10.1108/17506161011065217

Jones, C. (2005). Firm transformation: advancing a Darwinian perspective. Management Decision, 43(1), 13-25. https://doi.org/10.1108/00251740510572452

Kets, de V. M., \& Balazs, K. (1998). Beyond the Quick Fix: The Psychodynamics of Organizational Transformation and Change. European Management Journal, 16(5), 611-622. https://doi.org/10.1016/S0263-2373(98)00037-1

Kromidha, E. (2012). Strategic e-government development and the role of benchmarking. Government Information Quarterly, 29(4), 573-581. https://doi.org/10.1016/j.giq.2012.04.006

Laughlin, R. (1987). Accounting systems in organisational contexts: A case for critical theory. $\begin{array}{llll}\text { Accounting Organizations } & \text { Society, } & \text { 42(5), }\end{array}$ https://doi.org/10.1016/0361-3682(87)90032-8

Levine, C., Backoff, R., Cahoon, A., \& Siffin, W. (1975). Organizational design: A post-Minnowbrook perspective for the 'new' public administration. Public Administration Review, 35, 425-435. https://doi.org/10.2307/974548

Lounsbury, M. (2008). Institutional rationality and practice variation: New directions in the institutional analysis of practice. Accounting Organizations and Society, 33(4-5), 349-361. https://doi.org/10.1016/j.aos.2007.04.001 
Maguire, S., Hardy, C., \& Lawrence, T. B. (2004). Institutional entrepreneurship in emerging fields: HIV/AIDS treatment advocacy in Canada. Academy of Management Journal, 47(5), 657-679. https://doi.org/10.2307/20159610

Mayring, P. (2008). Qualitative Inhaltsanalyse. Weinheim, Germany: Beltz Verlag.

Meier, R., Ben, E. R., \& Schuppan, T. (2013). ICT-enabled public sector organizational transformation: Factors constituting resistance to change. Information Polity, 18(4), 315-329.

Mergel, I. (2013). A framework for interpreting social media interactions in the public sector. Government Information Quarterly, 30(4), 327-334. https://doi.org/10.1016/j.giq.2013.05.015

Moran, J. W., \& Brightman, B. K. (2001). Leading organizational change. The Career Development International, 6(2), 111-118.

Myers, M. D., \& Newman, M. (2007). The qualitative interview in IS research: Examining the $\begin{array}{lllll}\text { craft. Information } & \text { and } & \text { Organization, }\end{array}$ https://doi.org/10.1016/j.infoandorg.2006.11.001

Nutt, P. (2006). Comparing Public and Private Sector Decision-Making Practices. Journal of Public Administration Research and Theory, 16(1), 289-318. https://doi.org/10.1093/jopart/mui041

Nutt, P., \& Backoff, R. (1993). Organizational publicness and its implications for strategic management. Journal of Public Administration Research and Theory, 3(2), 209-231.

O'Grady, W., Rouse, P., \& Gunn, C. (2010). Synthesizing management control frameworks. Measuring Business Excellence, 14(1), 96-108. https://doi.org/10.1108/13683041011027481

Orlikowski, W. (1992). The Duality of Technology: Rethinking the concept of technology in organizations. Organization Science, 3(3), 398-427. https://doi.org/10.1287/orsc.3.3.398

Paré, G. (2004). Investigating Information Systems with Positivist Case Study Research. Communications of the Association for Information Systems, 13(1), 233-264.

Patton, M. Q. (2002). Qualitative Research and Evaluation Methods. Thousand Oaks, CA: Sage Publications.

Puron, C. G., Gil, G. R., \& Luna, R. L. (2012). IT-Enabled Policy Analysis: New Technologies, Sophisticated Analysis and Open Data for Better Government Decisions. Proceedings of the 13th Annual International Conference on Digital Government Research, College Park, 97-106. https://doi.org/10.1145/2307729.2307746

Roberts, H. (1994). Accountability and responsibility: the influence of organization design on management accounting. European Accounting Review, 3(2), 384-388. https://doi.org/10.1080/09638189400000027

Sabherwal, R., Hirschheim, R., Goles, T. (2001). The Dynamics of Alignment: Insights from a Punctuated Equilibrium Model. Organization Science, 12(2), 179-197. https://doi.org/10.1287/orsc.12.2.179.10113 
Sharma, C. (2012). Determinants of PPP in infrastructure in developing economies. Transforming Government: People, Process and Policy, 6(2), 149-166. https://doi.org/10.1108/17506161211246908

Sharma, U., Lawrence, S., \& Lowe, A. (2010). Institutional contradiction and management control innovation: A field study of total quality management practices in a privatized telecommunication company. Management Accounting Research, 21(4), 251-264. https://doi.org/10.1016/j.mar.2010.03.005

Suddaby, R., Hardy, C., \& Huy, Q. N. (2011). Where are the new theories of organization? Academy of Management Review, 36(2), 236-246. https://doi.org/10.5465/AMR.2011.59330875

Tarschys, D. (2002). Time Horizons in Budgeting. OECD Journal on Budgeting, 2, 77-103. https://doi.org/10.1787/budget-v2-art10-en

Tushman, M. L., \& O’Reilly, C. A. (1996). Ambidextrous Organizations: Managing Evolutionary and Revolutionary Change. California Management Review, 38(4), 8-30. https://doi.org/10.2307/41165852

Van de Ven, A. H., \& Poole, M. S. (1995). Explaining development and change in organizations. Academy of Management Review, 20(3), 510-540. https://doi.org/10.2307/258786

Vander, E. S., \& De Rynck, F. (2014). Alignment processes in public organizations: An interpretive approach. Information Polity, 19(3), 195-206.

Warner, M. E., \& Hefetz, A. (2012). Insourcing and Outsourcing: The Dynamics of Privatization Among US Municipalities 2002-2007. Journal of the American Planning Association, 78(3), 313-327. https://doi.org/10.1080/01944363.2012.715552

Webster, J., \& Watson, R. T. (2002). Analyzing the past to prepare for the future: Writing a literature review. MIS Quarterly, 26(2), 13-23.

Yin, R. K. (2008). Applications of Case Study Research. Thousand Oaks, CA: Sage.

\section{List of Abbreviations}

ERP: Enterprise Resource Planning

IM: Information Management [Organizational Unit from the Case Study]

IT: Information Technology

OECD: Organization for Economic Co-operation and Development

RQ: Research Question

SOE: State-Owned Enterprise 


\section{Appendix}

The following tables provide additional details on the characteristics and the process of the literature review. Table A.1 shows the taxonomy of the literature review based on six characteristics according to Cooper (1988).

Table A.1. Taxonomy of literature reviews (adapted from Cooper 1988)

\begin{tabular}{|c|c|c|c|c|}
\hline Charcteristic & \multicolumn{4}{|c|}{ Categories } \\
\hline (1) Focus & $\begin{array}{l}\text { Research } \\
\text { findings }\end{array}$ & $\begin{array}{l}\text { Research } \\
\text { methods }\end{array}$ & Theories & $\begin{array}{l}\text { Practices or } \\
\text { applications }\end{array}$ \\
\hline (2) Goal & Integration & \multicolumn{2}{|c|}{ Criticism } & $\begin{array}{l}\text { Identification of } \\
\text { central issues }\end{array}$ \\
\hline (3) Organization & Historical & \multicolumn{2}{|c|}{ Conceptual } & Methododical \\
\hline (4) Perspective & \multicolumn{2}{|c|}{ Neutral representation } & \multicolumn{2}{|c|}{ Espousal of position } \\
\hline (5) Audience & $\begin{array}{l}\text { Spcialized } \\
\text { scholars }\end{array}$ & $\begin{array}{l}\text { General } \\
\text { scholars }\end{array}$ & $\begin{array}{l}\text { Practioners or } \\
\text { policymakers }\end{array}$ & General public \\
\hline (6) Coverage & Exhausitve & $\begin{array}{l}\text { Exhaustive with } \\
\text { selective citation }\end{array}$ & Representative & $\begin{array}{l}\text { Central or } \\
\text { pivotal }\end{array}$ \\
\hline
\end{tabular}

The literature review considers the following journals: Accounting, Auditing \& Accountability Journal (AAAJ), Abacus, Accounting Horizons (AH), Accounting Organizations and Society (AOS), Accounting Review (AR), British Accounting Review (BAR), Contemporary Accounting Research (CAR), Critical Perspectives on Accounting (CPA), European Accounting Review (EAR), International Journal of Public Sector Management (IJPSM), Journal of Accounting and Economics (JAE), Journal of Accounting Research (JAR), Journal of Management Accounting Research (JMAR) and Management Accounting Research (MAR), Measuring Business Excellence (MBR), Management Decision (MD), Public Management Review (PMR), Information Polity (IP), Government Information Quarterly (GIQ), Transforming Government: People, Process and Policy (TGPPP) and International Journal of Electronic Government Research (IJEGR).

Table A.2 shows the number of found articles ('hits') in the different journals, in total 514. The column 'Relevance' indicates the number of articles that are considered for further analysis according the exclusion process of the literature review. 
Table A.2: Summary of the literature review

\begin{tabular}{|c|c|c|c|c|c|}
\hline Journal & Database & Search term & Search fields & Bits & Relevance \\
\hline Accounting, Auditing \& Accountability Journal & Emerald Insight & \multirow{21}{*}{$\begin{array}{l}\text { 'organizational } \\
\text { change' }\end{array}$} & \multirow{21}{*}{$\begin{array}{c}\text { Title } \\
\text { Abstract } \\
\text { Keywords }\end{array}$} & 31 & 1 \\
\hline Abacus & EBSCOhost & & & 1 & 0 \\
\hline Accounting Horizons & EBSCOhost & & & 0 & 0 \\
\hline Accounting Organizations and Society & Science Direct & & & 57 & 8 \\
\hline Accounting Review & EBSCOhost & & & 4 & 0 \\
\hline British Accounting Review & Science Direct & & & 16 & 0 \\
\hline Contemporary Accounting Research & EBSCOhost & & & 0 & 0 \\
\hline Critical Perspectives on Accounting & Science Direct & & & 29 & 0 \\
\hline European Accounting Review & EBSCOhost & & & 7 & 1 \\
\hline International Journal of Public Sector Management & Emerald Insight & & & 83 & 0 \\
\hline Journal of Accounting and Economics & Science Direct & & & 4 & 0 \\
\hline Journal of Accounting Research & Wiley Online Library & & & 2 & 0 \\
\hline Journal of Management Accounting Research & AAA Digital Library & & & 0 & 0 \\
\hline Management Accounting Research & Science Direct & & & 58 & 4 \\
\hline Measuring Business Excellence & Emerald Insight & & & 22 & 2 \\
\hline Management Decision & Emerald Insight & & & 147 & 3 \\
\hline Public Management Review & EBSCOhost & & & 18 & 0 \\
\hline Information Polity & EBSCOhost & & & 3 & 0 \\
\hline Government Information Quarterly & EBSCOhost & & & 20 & 0 \\
\hline Transforming Government: PPP & Emerald Insight & & & 5 & 0 \\
\hline International Journal of e-Government Research & InfoSci-On Demand & & & 7 & 0 \\
\hline Total & & & & 514 & 19 \\
\hline
\end{tabular}

\section{Copyright Disclaimer}

Copyright for this article is retained by the author(s), with first publication rights granted to the journal.

This is an open-access article distributed under the terms and conditions of the Creative Commons Attribution license (http://creativecommons.org/licenses/by/4.0/). 